
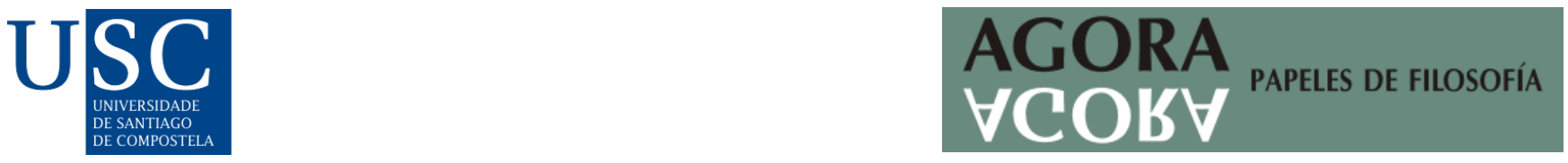

\title{
DECISIÓN COMO CURSO, MITO COMO RECURSO. UNA CRÍTICA AL DECISIONISMO SCHMITTIANO
}

\author{
Joan Morro Delgado ${ }^{1}$ (iD \\ ${ }^{1}$ Universidad Nacional de Educación a Distancia, España
}

Recibido: 24/01/2021; Aceptado: 30/06/2021

\section{Resumen}

El decisionismo schmittiano es uno de los tópicos principales de la filosofía política contemporánea. Es a menudo recurrido entre quienes critican el liberalismo político, sea en su forma parlamentaria o mecanicista. El objetivo de este artículo es explicitar los cimientos, las implicaciones y las tesis más problemáticas de este decisionismo desde un planteamiento alternativo al de la fe. Se intenta mostrar tanto la presencia de Kierkegaard como el rechazo de Hegel en el reto que Schmitt presenta a la filosofía política, así como reinterpretar sus concepciones del mito y la soberanía en un marco crítico con el pensamiento liberal. Concluyo sosteniendo que los sesgos conceptuales de Schmitt comportan un absolutismo político no menos criticable.

Palabras clave: Carl Schmitt; decisionismo; mito; política; soberanía

\begin{abstract}
Schmittian decisionism is one of the main topics of contemporary political philosophy. It is often appealed among those who criticize political liberalism, whether in its parliamentary or mechanistic way. The aim of this article is to explain the foundations, implications, and most problematic thesis of this decisionism from an alternative approach to that of faith. It is attempted to show both Kierkegaard's presence and Hegel's rejection in Schmitt's challenge to political philosophy, as well as to reinterpret his conceptions of myth and sovereignty in a critical frame of liberal thought. I conclude by arguing that Schmitt's conceptual biases entail a political absolutism that deserves no less criticism.
\end{abstract}

Keywords: Carl Schmitt; decisionism; myth; politics; sovereignty

\section{INTRODUCCIÓN}

Carl Schmitt es una referencia clave de un planteamiento controvertido en su forma original y en su defensa actual: el decisionismo. Argumento esto articulando lo siguiente: 
- Conecto el decisionismo con una teoría de la soberanía y a ambas con el objetivo de ordenar un espacio vital, lo cual cuenta con cimientos tales como el catolicismo reaccionario, el antiparlamentarismo de entreguerras y el pensamiento teológico de Kierkegaard.

- Expongo el desarrollo original que Schmitt supone en la historia del pensamiento con su concepción del soberano, presentado como un patriarca que «decide» en función de lo que llama nomos y que, a su vez, choca con las filosofías derivadas del liberalismo y el marxismo. - Señalo cómo dicha decisión, según Schmitt, implica una fuerza «mítica» que granjea un nosotros auténtico de acuerdo con lo presuntamente nacional en tiempos de crisis del parlamentarismo y se contrapone a su principal alternativa histórica: la lucha de clases en su versión hegeliano-marxista.

- Como síntesis, comento por qué la propuesta de Schmitt comporta un absolutismo político con bases arbitrarias que, no obstante, se arroga la capacidad de descartar el resto de propuestas y de regenerar el orden en sintonía con una presunta "nueva política".

\section{EL DECISIONISMO SCHMITTIANO}

«Es soberano quien decide el estado de excepción» (Schmitt 2001a: 23). Esta es la idea nuclear de la teoría de la soberanía de Schmitt y del decisionismo schmittiano. Son dos ojos de una misma mirada: sin uno, se pierde profundidad. Hoy, entre otros problemas filosófico-políticos, se postula tanto para comentar las vicisitudes del poder soberano en relación con las gestiones del COVID-19 (Agamben 2020, Han 2020) como para construir y ejercer políticas alternativas frente a las heredadas y realmente operantes (Marchart 2009, Mouffe 2011). Pero, en todo caso, es el deseo de ordenar el espacio vital lo que movió al jurista alemán a desarrollar la mirada en cuestión.

El decisionismo schmittiano tiene cimientos teológicos y políticos. Ninguno es ortodoxo ni meramente gremial, ni se supeditan exclusivamente a la vocación católica o a la adscripción nazi de Schmitt. No escribía ni para teólogos ni para políticos, ni aspiraba a clasificarse entre unos u otros, y parece que era consciente de ello ${ }^{1}$. Sus escritos ni siquiera generan un cuerpo ideológicamente intransferible. Tales cimientos se enmarcan en debates teórico-filosóficos y práctico-jurídicos, en ambos casos de compleja actualidad.

Sus cimientos teológicos remiten, de forma específica, a Sören Kierkegaard. Su presencia en este jurista sigue siendo poco explorada, aunque la haya señalado un comentarista tan influyente como Agamben (Agamben 1998: 29), se haya explicitado en trabajos sugerentes (Campos GarcíaCalderón 2021, Conrad 2008, Löschenkohn 2019) y Schmitt dijera de él que, aun siendo protestante, puso de manifiesto la intensidad de la reflexión teológica de su tiempo (Schmitt 2001a: 29). Los motivos por los que acude al pensador danés se deben a su condición de teólogo cristiano y -sobre todo- por ser un declarado adversario de Hegel. Ambos tienen un denominador común aquí. El enfrentamiento no se debe a un rechazo directo del profesor de Jena, sino a lo que representa en su momento: la racionalización de la realidad histórica y, por tanto, de la existencia humana. No es casual que Kierkegaard contraponga a Hegel con lo que llama caballero de la fe, el individuo auténtico, al que identifica con el patriarca Abraham y de quien decía que sólo podía admirarlo pese a no poder comprenderlo (Kierkegaard 2005: 83,182). Por su parte, Schmitt valora la obra de juventud de su compatriota, pero lamenta que peregrinara de la mano de Marx a Moscú y que, tras la Primera Guerra Mundial, alcance su máxima vitalidad en marxistas como Lukács (Schmitt 2006: 90-91). Las referencias del lamento son lo más significativo. 
Más conocido es el vínculo de Schmitt con Joseph De Maistre, Louis De Bonald y Juan Donoso Cortés, a quienes llama «filósofos católicos del Estado» y a partir de los cuales señala la importancia de la «decisión» contra los procesos de modernización (Schmitt 2001a: 54). Así y todo, es superficial suponer que sólo los mencione porque son contrarrevolucionarios. El motivo convoca a la filosofía y es tan profundamente antihegeliano como su atracción por Kierkegaard: en sus pensamientos reaccionarios no hay hueco para encajar lo que llega con el siglo XIX. Hegel es el gran filósofo de la historia, entendiéndola como proceso de procesos, donde el conflicto y la superación [Aufhebung] son la tónica, y, en tiempos de Schmitt, además, el recurso filosófico de los pensadores marxistas contrarios al mecanicismo y "los milagros". Esta atención rigurosa por lo histórico (y no sólo con el pasado) y la conexión con el marxismo chocan con los contrarrevolucionarios y son incompatibles con el decisionismo schmittiano.

Los cimientos políticos del decisionismo schmittiano hay que buscarlos, en primer lugar, en la reacción de Schmitt al parlamentarismo de entreguerras y, en concreto, en el artículo 48 de la constitución de la República Weimar. Como ha dicho Carlo Galli, su tan comentado estado de excepción [Ausnahmezustand], sin el cual apenas son pensables sus ideas de decisión y soberanía, es una radicalización extremista del estado de necesidad [Notzustand] presentado en dicho artículo (Galli 2011: 65). En la primera edición de Teología Política, de 1922, dice que este reconoce que el Estado tiene autonomía para declarar el estado de excepción (Schmitt 2001a: 27). Sin esta declaración, su teoría de la soberanía, su consiguiente apelación al mito e incluso su nombre en los debates de la época carecen de todo arranque sustancial. Sus reflexiones sobre lo mítico en la política y el consiguiente rechazo del parlamentarismo están influidas por las del teórico y líder anarcosindicalista francés Georges Sorel, a quien recurre expresamente en su obra sobre la crisis de este sistema de gobierno, publicada al año siguiente de presentar su teoría de la soberanía; no en balde, en el período de entreguerras, Schmitt era identificado como soreliano (Rossi 1999: 147). Otro cimiento político de su pensamiento radica en su compromiso con el nacionalsocialismo como «movimiento» en contraposición a la «norma» y el «pueblo», tal como aclara tras el triunfo electoral de los nazis (Schmitt 2001a: 22). Esto implica la valoración de la coyuntura puntual favorable a una causa concreta en detrimento de la administración estatal y la pluralidad de intereses.

Los cimientos mencionados postulan una misma idea clave, cuya naturaleza y problemática es la distinción entre Historia y Razón, entendidas respectivamente como una secularización de "alma" y "cuerpo". Como dijera Wilhelm Windelband a finales del siglo XIX, esta distinción implica un despliegue de la que hiciera Kant entre el noúmeno y el fenómeno, entre lo indeterminado y lo determinado, entre los valores y la naturaleza, en clave de confrontación política a partir de la acusación de "traición histórica" que De Bonald dirigió a los revolucionarios (Windelband 1960: 573). Esta distinción, pues, supone la traslación del dualismo kantiano a la política contemporánea.

Para Schmitt y sus referentes reaccionarios la Historia es un fetiche. En el mejor de los casos, una invocación a Dios en una supuesta situación límite, el acabose ante el cual se clama al Cielo para que todo vuelva a su cauce, como si el orden espiritual y su realización terrenal preexistieran y entre ambos hubiera alguna relación necesaria. La Historia así presentada es un reinicio para poder seguir adelante. Frente a esta, la Historia descubierta por Hegel comporta que lo que no es, mal que pese, puede llegar a ser y que lo que es, aunque haya sido, no tiene por qué seguir siendo. En esta sucesión temporal y radicalmente dialéctica, la Historia y la Razón se entremezclan hasta tal punto que su diferenciación es meramente analítica y hacen que todo cambio sea razonable y de la razón, historia. Por su parte, desarrollando ideas de los contrarrevolucionarios con la ayuda de 
Kierkegaard y en oposición a la República de Weimar, Schmitt sostiene que el auténtico cambio y lo propiamente histórico está y ha de estar más allá de la racionalidad.

El decisionismo presupone la distinción entre Historia y Razón y el consiguiente fetiche. Ahora bien, aunque la vinculación entre decisionismo y Schmitt sea evidente, pues él acuña el concepto (Schmitt 2001a: 41), el enfoque decisionista es problemático. La gravedad del problema implica dos extremos discutibles y un filósofo ineludible. Por un lado, se ha presentado el pensamiento de Schmitt como el paradigma del decisionismo. Por otro, también se ha dicho que el planteamiento schmittiano implica decisionismo, ciertamente, pero que no es esencialmente decisionista. Montserrat Herrero dice que «la decisión schmittiana no es puro decisionismo», puesto que «es la desembocadura de un orden previo» (Herrero 2007: 123, 160). Diferencia entre el decisionismo clásico, que es el de Hobbes, y el schmittiano; mientras que el hobbesiano sería un decisionismo absolutista prácticamente indiferenciable del positivismo jurídico, ya que antes de la decisión sólo es concebible el caos y aquélla se realiza en virtud de la Ley, presenta el schmittiano como un decisionismo tendencialmente relativista, aunque no por ello subjetivista, pues implica un acto prudente de acuerdo con un orden concreto (Herrero 2007: 157-165). Sea cual sea la consideración de este matiz, Hobbes es un autor relevante para comprender el decisionismo schmittiano.

Es Schmitt quien dice que el representante clásico del decisionismo es el autor del Leviatán (Schmitt 2001a: 41). Lo llama «el gran decisionista» en una monografía que le dedica en tiempos del III Reich (Schmitt 2004: 49). En esta misma obra, no obstante, lo acusa de ser el «precursor espiritual del Estado de derecho y del Estado constitucional burgués que a lo largo del siglo XIX se impone en todo el ámbito del continente europeo» (Schmitt 2004: 40, 61); en relación con esto, en un prólogo firmado en noviembre de 1933 de una edición de Teología Política, declara que la política de Weimar es una combinación de normativismo y decisionismo degenerados y señala una alternativa a ambos en cuanto a las concepciones del derecho (Schmitt 2001a: 22). Pero, más allá de que sea un decisionista más o menos de su agrado, Schmitt encuentra en Hobbes lo que cree que necesita toda causa política contemporánea: un mito al servicio de su nación.

\section{¿QUIÉN DECIDE Y EN VIRTUD DE QUÉ?}

Lo que caracteriza al decisionismo schmittiano, incluso frente al clásico de Hobbes, es que la decisión del estado de excepción por el que el soberano se afirma como tal no es correcta ni incorrecta. Supone una autonomía de lo político sui generis. Según Schmitt, está "más allá de lo correcto y lo incorrecto", ya que es la condición de posibilidad de toda corrección e incorrección.

El hecho de haber sido la autoridad competente la que tomó una decisión la torna, en términos relativos, tal vez también absolutos, independiente de la circunstancia de que su contenido sea correcto y omite la discusión sobre si aún persiste alguna duda. En ese instante la decisión se independiza de la fundamentación argumentada y adquiere un valor autónomo. La significación teórica y práctica de este hecho se pone de manifiesto en la teoría del acto estatal equivocado. A la decisión incorrecta y equivocada corresponde un efecto legal. La decisión incorrecta posee un elemento constitutivo precisamente debido a su incorreción. No obstante, es inherente a la idea de la decisión la imposibilidad de que exista una decisión declarativa absoluta. Desde el punto de vista del contenido de la norma en que se basa la decisión, aquel elemento constitutivo y específico de la decisión representa algo nuevo y ajeno. En términos normativos, la decisión surge de la nada. La fuerza jurídica de la decisión es algo distinto del resultado de su fundamentación. La atribución no se establece con la ayuda de una norma sino al revés: el punto de atribución determina qué es la norma y cuál la verdadera normativa. (Schmitt 2001a: 40) ${ }^{2}$ 
La pregunta por quién decide y en virtud de qué, según el decisionismo schmittiano, está implícito en estas líneas de Teología Política. La respuesta remite a una suerte de patriarca de connotaciones bíblicas ya ensayado desde una teología antihegeliana.

No extraña que Schmitt apele a una autoridad competente al tratar el problema de la soberanía, porque el acto soberano implica la decisión y esta a quien la lleva a cabo, pero es llamativo desde un enfoque histórico y filosófico. Este planteamiento supone una ruptura con las teorías de la soberanía precedentes, incluida la de Hobbes. En un capítulo del Leviatán dedicado al poder eclesiástico y que, por tanto, debería llamar la atención de un "teólogo político" como Schmitt, el filósofo inglés afirma respecto al soberano que tiene poder sobre las acciones y las palabras de cualquiera, pero no sobre los "corazones", pues estos sólo los conoce Dios (Hobbes 1909: 428). Además, reconoce que dicho poder se reconoce en la Jurisdicción, que prescribe el Bien y el Mal, y se ejecuta con "la espada de la Justicia" mediante decisiones [Decisions] (Hobbes 1909: 444). Quien decide en este caso es soberano de facto y es competente en tanto que lo que ejecuta son leyes.

La política y la ética para Hobbes son subproductos del contrato social, de un pacto público y en principio acordado, que no es estrictamente arbitrario porque sus posibles afectados pueden prever la decisión soberana según lo que hagan. Esto posibilita la paradójica libertad de los súbditos, y es por lo que hacer valer la Ley es supuestamente deseable y lo único que vale en cuestiones de disputa social o dilemas morales. Schmitt no puede estar más en desacuerdo en este punto. A su juicio, el soberano es competente si y sólo si se acoge al nomos, a un orden espiritual, no a la Ley.

La autoridad competente para Schmitt no es quien hace valer un contrato, más o menos ficticio pese a ser aceptado y legitimar el uso de "la espada", sino quien reclama un curso que le preexiste y por el cual puede existir, como lo es el curso de las aguas de un río para los peces que en él siempre han habitado. Este curso es lo que llama nomos y al que le dedicó la principal obra que escribió tras la Segunda Guerra Mundial, El nomos de la tierra. En un texto publicado como Separata del Boletín Informativo del Seminario de Derecho Político de la Universidad de Salamanca, a fin de aclarar los conceptos clave de dicha obra para sus lectores de la España franquista, señala que nomos es un substantivo del griego clásico que proviene del verbo nemein (Schmitt 2003b: 363). A partir aquí, señala tres interpretaciones: apropiación, partición y apacentamiento. Schmitt trata de conjugarlas al afirmar que «[e]n cualquier estado de la convivencia humana, en cualquier ordenación económica y laboral, en cualquier sector de la historia del derecho, se ha venido, hasta hoy, de alguna manera tomando, partiendo y produciendo» (Schmitt 2003b: 364). Pero es tajante al declarar que la apropiación ha sido prioritaria respecto a la partición y el apacentamiento hasta el siglo XX, cuando en los países comunistas y las democracias liberales se invierte la prioridad, haciendo que la distribución y la producción acaben ninguneando la toma del espacio (Schmitt 2003b: 366, 369). Es llamativo que acuse a Marx de teorizar lo que acuña como "antisituacionalidad" [situatioswidrigkeit] de la distribución que crece con el aumento de la producción y acabará por destruirse a sí mismo (Schmitt 2003b: 371). Según Schmitt, esto no deriva de ningún moralismo beligerante, como era recurrente en los anarquistas en su crítica del capitalismo, por quienes a menudo muestra una turbia simpatía, sino de un planteamiento histórico-filosófico.

Para Marx, la apropiación no es un acto en sí mismo, pues es sobre la partición y el apacentamiento. Los marxistas congenian en esto con los liberales demócratas: la economía, la tecnología y los mecanismos para incrementarlos y socializarlos han diluido la cuestión de la toma de la tierra en tanto espacio vital por el que presuntamente nuestra especie se humaniza. Schmitt presupone que no hay humanos en sentido estricto al margen del nomos y es por esto por lo que a su parecer la política triunfante tras la Segunda Guerra Mundial, tanto capitalista como socialista, 
es deshumanizadora y conduce a la superficialidad; así lo probaría la creencia en la unidad del género humano o la dirección y planificación de la producción mundial unitaria (Schmitt 2003b; 374). Y no sólo esto: acusa a Marx de ser partidario de un «imperialismo extremo» al pretender «la expropiación de los expropiadores» (Schmitt 2003b: 372). Sugiere que el marxismo, además de ser imperialista como el liberalismo, radicaliza la doctrina liberal al querer reducir la vida humana a producción. Así, a su juicio, no sólo se niega el espíritu humano y la condición de posibilidad de este, lo cual es pretexto de los contrarrevolucionarios en su reproche al pensamiento moderno. También se erradica toda individualidad.

Desde el decisionismo schmittiano, la única salida frente a la deshumanización es la reapropiación del nomos, sin el cual no hay derecho. Sólo la decisión como curso reiniciado, como reconocimiento de la autenticidad, por el que somos más que animales, puede salvarnos. Esta apropiación soberana, de la que emerge «la verdadera normativa», no requiere de discusiones ni acepta divisiones. Schmitt muestra con esto su aversión al parlamentarismo y se muestra como un reaccionario. Su referencia filosófica aquí es Kierkegaard. Y es que dicha apropiación implica el salto ex nihilo en pos de la repetición, lo dado que es afirmado frente a la esperanza y el recuerdo que le convierte a uno en caballero de la fe, quien actúa en virtud del absurdo, dispuesto a sacrificar al propio hijo por orden divina (Kierkegaard 2018: 35, Kierkegaard 2005: 70). Esto desborda la racionalidad derivada del desarrollo histórico hegeliano y del contrato social hobbesiano.

Schmitt politiza los conceptos teológicos de Kierkegaard (Conrad 2008: 164). En especial, los de repetición [Gjentagelse] e instante [Øjeblikket], de sus obras de 1843 La repetición y Temor y temblor (Campos García-Calderón 2021: 87-91, Löschenkohn 2019: 90) ${ }^{3}$. Las obras de este autor empiezan a traducirse al alemán a partir de 1909 y se convierten en lugar común en la Alemania de entreguerras para teólogos, filósofos y politólogos (Adorno 2005: 396, Conrad 2008: 155-156). También para Schmitt ${ }^{4}$. Por esas fechas, remarca ásperamente que Lenin y Lukács se apropian para la lucha de clases de la siguiente frase de Hegel: «Las personas [...] que entienden la política como pequeños trucos que en ocasiones lindan con el engaño tienen que ser resueltamente rechazadas por nosotros» (Schmitt 2006: 92). Frente a esta idea hegeliana, por la que lo general se impone y sobrepone como sittlichkeit barriendo toda coyuntura abierta al oportunismo, Schmitt afirma públicamente en 1933 que «"Hegel ha muerto"» (Schmitt 2017: 296). Lo presenta como un agotado vestigio decimonónico.

El acta de defunción de Hegel que Schmitt simula no se presenta como una derrota. Le sirve para aproximarse al teólogo que declara que «[l]a fe consiste precisamente en la paradoja de que el Particular se encuentra como tal Particular por encima de lo general, y justificado frente a ello, no como subordinado, sino como superior» (Kierkegaard 2005: 112). Es por la fe que la acción concreta se abre a la repetición como alternativa a la mediación [Vermittelung] que caracteriza la síntesis histórico-racional hegeliana (Kierkegaard 2015: 70). Esta se abre a la novedad y supera las partes abocándose a la agónica globalidad del nosotros. Por el contrario, según Kierkegaard, «[l]a repetición es una esposa amada, de la que nunca jamás llegas a sentir hastío, porque solamente se cansa uno de lo nuevo, pero no de las cosas antiguas, cuya presencia constituye una fuente inagotable de placer y felicidad» (Kierkegaard 2018: 34). La politización de los conceptos kierkegaardianos comporta un compromiso con la Historia invocada por los contrarrevolucionarios, una historia ahistórica, la que presupone un curso que puede y debe reiniciarse, mantenerse indefinidamente, bajo un halo fetichista de autenticidad. No por casualidad, la reivindicación de la repetición frente a la mediación hegeliana supone para el pensador danés 
un motivo de orgullo romántico y una feliz regresión no ya a una mera situación preindustrial, sino a la Antigua Grecia ${ }^{5}$.

Para Kierkeggard, como decía Adorno, «la vida recta se define por la decisión sin más» (Adorno 2005: 472). Esto está tan lejos de Hegel cuanto cercano a Schmitt: la decisión auténtica comporta la excepción total. La arbitrariedad absoluta. Lo Particular por encima de lo general. Sin embargo, esto supone un curso, aunque indeterminado, pues de lo contrario no habría instantes para decidir. Lo que habría a lo sumo serían impulsos (Herrero 2007: 112). En términos kierkegaardianos, el instante es una categoría teológica que conecta al individuo con Cristo y, al mismo tiempo, un concepto filosófico que conecta lo individual con el curso de la historia y la necesidad de la decisión para la existencia (Conrad 2008: 145). Esta, si es genuina, presupone la decisión, cuyo modelo Kierkegaard lo encuentra en quien considera que para Hegel no podría ser sino un asesino: Abraham (Kierkegaard 2005: 111). Desde lo general, ha de ser rechazado, pues es un Particular que al disponerse a matar a Isaac atenta contra lo general y su normalidad, siendo despiadadamente soberano. Por esto, citando al pensador danés para concluir el primer capítulo de Teología Política, Schmitt dice que «[1] o normal no demuestra nada, la excepción lo demuestra todo; no sólo confirma la regla sino que la regla sólo vive gracias a aquélla. En la excepción, la fuerza de la verdadera vida rompe la costra de un mecanismo cuajado en la repetición» (Schmitt 2001a: 29). Abraham desvela el auténtico curso al actuar en virtud del absurdo.

Aunque sea determinante para Schmitt, no parece justificado inferir que Kierkegaard sea un schmittiano avant la lettre. Valga recordar que al danés no le interesa salvar a ningún colectivo, ni mucho menos reivindicar un espacio vital para este. De hecho, pese a lo comentado, Schmitt probablemente veía en Kierkegaard a un romántico individualista a la postre políticamente irrelevante. Esto nos lleva a la cuestión del mito.

\section{LA POLÍTICA DEL MITO COMO “NUEVA POLÍTICA”}

El mito es un factor imprescindible del decisionismo schmittiano. Y es que es el recurso que permite al soberano aunar a quienes deben dar el salto ex nihilo con él. Apelando al mito, Schmitt no pretende fundamentar una filosofía, sino pasar a la acción. El mito contribuye a que el curso del nomos, el único genuino según Schmitt, identificable a la historia humana, pueda realizarse al ofrecer un pretexto para un nosotros auténtico.

Schmitt desarrolla la noción de mito con una finalidad antiliberal en Los fundamentos históricoespirituales del parlamentarismo en su situación actual. Esta obra ve la luz tras Teología Política y mediante una lectura atenta de Reflexiones sobre la violencia de Sorel. Este líder anarquista publica su texto en 1906, cuando el marxismo está diluido con la época e internamente dividido. Dice aborrecer a los socialistas que se convierten en políticos profesionales, que hablan «tantos lenguajes como especies hay de clientelas», y que olvidan que el porvenir de la causa socialista depende del mito de la huelga general, el cual entiende como «una organización de imágenes capaces de evocar de manera instintiva todos los sentimientos que corresponden a las diversas manifestaciones de la guerra entablada por el socialismo contra la sociedad moderna» (Sorel 2005: 109, 181). Sin este mito, según Sorel, el socialismo acabará entregándose a la burguesía.

Esta denuncia puede rastrearse entre socialdemócratas y comunistas desde el siglo anterior. No es exclusiva del anarquismo. Quien fuera presentado públicamente por Marx como "nuestro filósofo", además de ser una referencia en el movimiento obrero europeo y norteamericano, 
Joseph Dietzgen, ya diferenciaba entre materialismo mecanicista y marxista y, posteriormente, entre marxismo ortodoxo y hegeliano (Burns 2002: 218, 220-221). El mismo año en que Sorel publica el libro que tanto impacta a Schmitt, Thorstein Veblen da una conferencia en Harvard donde diagnostica que el socialismo estadounidense y el francés no sólo no son marxistas, sino que su credo comulga más con la teología que con la filosofía, y que el marxismo triunfante en Alemania ha substituido el materialismo de Marx por el de Darwin, así como, desde 1870, con la socialdemocracia, ha pasado de ser revolucionario a un patriotismo reformista, acercándose al liberalismo anglosajón (Veblen 1907: 307n, 315, 320-321). Cuando Schmitt publica su crítica del parlamentarismo, en 1923, el legado de Marx está tan disperso y desorientado en Europa que Karl Korsch denuncia que los pensadores burgueses y los militantes socialistas en tiempos de la II Internacional estaban de acuerdo en que el marxismo no tiene nada que ver con la filosofía: mientras que los primeros lo hacían para restarle valor, los segundos lo hacían para encomiarlo (Korsch 1978: 78-79). Todo esto lleva a Schmitt a descartar compatibilidades entre marxismo y decisionismo. Los marxistas no tienen nomos.

La convicción de que el mito es el recurso para revivir la política tras su neutralización y decadencia hace que Schmitt se tome seriamente a Sorel. Pero no es un soreliano. Frente al mito de la huelga general, entiende que la lucha de clases es un mito que hace temibles a los comunistas y, tras la Segunda Guerra Mundial, también reconoce que los americanos tienen el suyo, la guerra justa (Schmitt 2003a: 108-109, Schmitt 2008: 143). Asimismo, supone que el mito es algo más que imágenes, pues tiene que ver con una lucha secular (Schmitt 2004: 2). Esto implica que la imagen mítica, para ser tal, presuntamente humanizadora, ha de reconocer a Dios en un espacio vital amenazado; por esto, en su ensayo sobre Hobbes, de 1938, afirma cosas tales como que la imagen del "Leviatán" en el contexto inglés del siglo XVII es un mito al que se recurre intencionadamente, que la imagen nietzscheana según la cual "el Estado es el más frío de los monstruos" no es mítica, sino tan solo sugestiva e impresionista, y que la imagen que de Maquiavelo se ha hecho con el "maquiavelismo" ha servido como mito favorable a los poderes fácticos europeos desde el siglo XVI (Schmitt 2004: 1-2, 16, 76-77). A todo esto, frente a Sorel, Schmitt sostiene que la nación es el único mito válido tras la crisis del parlamentarismo.

Schmitt dice que el mito nacional es superior al de la lucha de clases (Schmitt 2008: 150). ¿Por qué? Pienso que pueden encontrarse tres ideas clave en su planteamiento. La primera es que la lucha de clases no se reduce a imágenes concretas. Y mucho menos vinculadas a un espacio concreto. Así, no tiene nada que ver con el mito que Schmitt reconoce en el Leviatán de Hobbes ${ }^{6}$, ya que este mito marxista está configurado ante todo por creencias colectivas y subordinadas a objetivos anticapitalistas. Es sólo en virtud de esto que este recurso está más o menos ligado a imágenes. Pero, en cualquier caso, estas varían según el contexto ${ }^{7}$ y comportan y conservan una fraseología derivada del Manifiesto Comunista. Otra idea es que el hecho de que la lucha de clases implique creencias, y no sólo imágenes, la hace susceptible de narraciones a menudo imprevisibles y con tendencia a la racionalización en sentido hegeliano. De ahí que no sólo haya diversos marxismos, sino que los marxistas acaben defendiendo posturas contrarias entre sí y a las de Marx.

Al acabar la Primera Guerra Mundial, entre estupor y sorna, Schumpeter decía que Marx:

[...] se reiría ásperamente de aquellos de sus discípulos que saludan a la presente economía administrativa considerándola el amanecer del socialismo, la economía administrativa, que es la cosa menos democrática que existe, ese paso hacia atrás, hacia lo que precedió a la economía de competencia; la única que puede crear las condiciones previas para el verdadero socialismo y finalmente evolucionar hacia el socialismo mismo. (Schumpeter 2000: 192) 
Para más inri, se ha dicho que el artículo donde aparece este comentario fue determinante para que marxistas con responsabilidades políticas ofrecieran a Schumpeter el ministerio de finanzas de la naciente República Austríaca, cargo al que acabó accediendo pese a no ser socialista (Swedberg 1991: 58-59). Todo esto es reprobable desde el decisionismo schmittiano. El rechazo de las discusiones y de las posibles divisiones en torno a problemas y temas políticamente cruciales fue un leitmotiv de los contrarrevolucionarios a los que Schmitt siempre admiró.

Una tercera idea apunta a la conexión entre el espíritu ilustrado y la lucha de clases. Este mito marxista se concibió desde una historia razonada, es decir, no "racional sin más", lo cual sería poco menos que un salto kierkegaardiano, sino explicable por la conjugación crítica de los diversos enfoques teóricos de inspiración racionalista. Este planteamiento contradice al mito (Schmitt 2008: 144, 148). Según Schmitt, lo mítico está localizado, estrechamente ligado espacialmente y a presuntas perspectivas inconmensurables y exclusivas, y se diferencia del «hecho científico y medible» y del «acontecimiento jurídico» (Schmitt 2003a: 67, 108-109). El mito es una alternativa a la razón. Por su parte, desarrollando la filosofía hegeliana de la historia, en su versión tanto mecanicista como crítica, el marxismo entiende la lucha de clases como un fenómeno cuyo origen, desarrollo y culminación pueden y han de explicarse en una sucesión de hechos históricos. Esta lucha es contraria al nomos y condiciona toda decisión soberana, hasta el punto que la soberanía aparece como la cresta de una ola, un epifenómeno de causas conocibles, mostrando que la historia es un curso contradictorio que avanza sin posibilidad de retorno ni garantía de repetición o anamnesis. Y, con todo, es objeto de razón.

Schmitt dice que quien mejor representa esto es Lenin. Las tesis que presenta sobre el imperialismo poco antes de la Revolución de Octubre toman forma a partir de una reflexión sobre un discurso de Chamberlain. Según el jurista, este presentó un programa basado en el nomos al sostener que, para que haya partición y apacentamiento, es preciso que previamente haya apropiación. Esto se traducía en una política imperialista como condición de supervivencia del capitalismo. Lenin dedujo que esto estaba condenado a fracasar por reproducir un modelo clásico que obviaba todo conocimiento posterior a la Revolución Industrial.

Que al reparto y a la producción hubiera de anteponerse la expansión imperialista, es decir, un tomar, y en particular la toma de tierras, era un orden de prelación que a un socialista como Lenin tenía que antojársele algo ya de suyo medieval, por no decir atávico, reaccionario, opuesto al progreso, y en definitiva inhumano. Y no le fue difícil a la repulsión moral de Lenin encontrar en el arsenal de la filosofía de la historia progresista, no menos que en el de la marxista, gran número de argumentos aniquiladores contra un enemigo tan reaccionario, que quería tomar algo a otros, mientras él, Lenin, se afanaba simplemente en desarrollar las fuerzas productivas y electrificar el planeta.

He aquí el punto donde el socialismo coincide con la economía política clásica y su liberalismo. (Schmitt 2003b: 368)

Schmitt cree que el mito nacional es puro, auténtico, y que el de la lucha de clases no lo es. Siente que una presunta pureza implica «movimiento», el curso que se repite, que desborda todo enfoque racional y que, como la furia de Dios, ha de imponerse tanto al Estado de Hobbes y el positivismo jurídico como al pueblo contradictorio de Hegel y el pensamiento marxista.

Sólo en el mito reposa el criterio para saber si un pueblo u otro grupo social tienen o no una misión universal y si ha llegado su momento histórico. El gran entusiasmo, la gran decisión moral o el gran mito surgirán de lo profundo de los auténticos instintos vitales, no de un razonamiento o de consideraciones prácticas. (Schmitt 2008: 138) 
Es su fe en esto lo que le hace decir que Mussolini ha iniciado una nueva época. Afirma que «ha sido de nuevo un italiano quien ha dado expresión al principio de la realidad política» (Schmitt 2008: 152). Dice que con Maquiavelo se inicia una época que termina tras la Primera Guerra Mundial. El parlamentarismo es su fase terminal y el comunismo poco más que su estertor. La nueva política depende de imágenes indiscutibles e irracionales. Así, según Schmitt, en el período de entreguerras llega la política del mito y la necesidad del decisionismo.

\section{EL DECISIONISMO COMO ABSOLUTISMO}

Schmitt entiende la decisión como un curso ante y por el cual el soberano cumple con una suerte de misión que es espiritual y sociopolítica. Cual caballero de la fe kierkegaardiano, el soberano schmittiano es testigo, no maestro: es por esto por lo que se le considera humano, una parte del nosotros, y no algo así como un Dios (Kierkegaard 2005: 143). El soberano importa por su decisión y esta importa porque, aprovechando la coyuntura, reúne a actores sociales cuya naturaleza no puede sino ser un nosotros que no es hegeliano, el de la mediación, pues es inquebrantable, homogéneo y enfrentado que, además, revitaliza lo que supuestamente ya estaba. He aquí la repetición frente a la mediación. Como diría Kierkegaard:

El mundo, desde luego, jamás habría empezado a existir si el Dios del cielo no hubiera deseado la repetición. Porque entonces una de dos, o Dios había seguido los planes fáciles de la esperanza, o se había contentado con evocar todas las cosas en su memoria, conservándolas en el recuerdo. Pero Dios no hizo ni lo uno ni lo otro, por eso hay mundo y subsiste gracias a que es cabalmente una repetición. La repetición es la realidad y la seriedad de la existencia. El que quiere la repetición ha madurado en la seriedad. (Kierkegaard 2018: 36)

Quien decide no crea: afirma como quien reafirma, retorna a un origen latente. Lo que es y ha sido ha de llegar a ser contra falsas esperanzas y vanos recuerdos. La repetición, como la anamnesis platónica (Kierkegaard 2018: 33), es inagotable, presente y a la vista de quien ha de recoger su testimonio. En Kierkegaard no hay huella de quietismo, pues llama a actuar, a un salto racionalmente incomprensible. Por eso Abraham, si se comunicara tras aceptar el filicidio que Dios le ordenó, sería un asesino a ojos de Hegel.

Las palabras del teólogo son politizadas -probablemente a pesar de Kierkegaard- por Schmitt. En 1934, con Hitler ya como Führer, en quien vislumbrara al patriarca que anuncia el resurgimiento de la eterna autenticidad, advierte lo siguiente:

Les parecerá inaudito que el Estado alemán actual posea la fuerza y la voluntad necesarias para distinguir entre sus amigos y sus enemigos. Nos prometerán sus alabanzas y los aplausos del mundo entero si de nueva cuenta nos postramos, igual que en aquella ocasión de 1919, para sacrificar nuestra existencia política ante los ídolos del liberalismo. El que aprecie el enorme trasfondo de nuestra situación política en conjunto comprenderá las exhortaciones y advertencias del Führer y se preparará para la gran batalla intelectual [geistigen] en la que hemos de defender nuestro derecho. (Schmitt 1934: 950, Schmitt 2001b: 118)

Lo inaudito que caracteriza al soberano, quien decide, aquel que distingue entre amigos y enemigos y no meramente se afirma cual presunto individuo auténtico, cual caballero de la fe, implica la autonomía de lo político. Lo que le parece inaudito a quienes idolatran el liberalismo ilustrado, a los modernos, a quienes reducen el acontecer a la racionalidad, es el curso mismo, la "historia" que los contrarrevolucionarios claman cual fetiche frente a la "razón" y por la que, gracias a la decisión soberana, se alumbra un nosotros. Con todo, el soberano no es Dios y es por esto por lo 
que requiere de recursos para su decisión. Aquí es clave el mito, en virtud del cual Schmitt advierte una gran batalla intelectual, una lucha por imponer la versión de la historia. Y, según el jurista, esta lucha se acabará decantando a favor de la nación y su nomos correspondiente.

Schmitt entiende el mito como un recurso para que el soberano pueda culminar su decisión y reiniciar así el curso espiritual de los grupos humanos, siempre ligados a un espacio vital y constituidos frente a otros. Su concepción de lo mítico hace que durante el período de entreguerras se aleje de Sorel, dado que, a diferencia del francés, supone que la fuente primaria de los mitos es la guerra (Rossi 1999: 153). De ahí que piense que el mito aparentemente alternativo al de nación no sea el de huelga general, sino la lucha de clases. Pero es su triple condición de discursividad crítica y razonable, a parte de la desconsideración del nomos en sentido schmittiano, lo que la hace caduca para Schmitt, para quien la nueva época política está marcada por imágenes indiscutibles e irracionales que el soberano ha de saber manejar. En tiempos de teleoligarquías populistas como las del siglo XXI, esta concepción del mito es sugerente. Sin embargo, el planteamiento de Schmitt no sólo determina cuál es el mito válido a priori, excluyendo cuanto cuestione lo nacional, sino que el decisionismo schmittiano ya supone que es dicha concepción y su expansión social lo único en lo que cabe confiar para el futuro de la política.

Schmitt no yerra al entender la decisión como un curso, pero es arbitrario que suponga que es espiritual, frente a los hechos. Puede decirse que su decisionismo carga un alfa y omega personal: es él quien pretende decidir cuál es el curso de la historia. La que imagina no sólo escapa a lo fáctico, cual "alma" sin "cuerpo", sino que ni siquiera acepta discusión. La base de este dogmatismo, sin embargo, no radica sólo en aspectos de vocación o adscripción, sino muy especialmente en la confusión. Schmitt reconoce la autonomía de lo político al percatarse de que lo que constituye un nosotros no está determinado por lo económico o lo moral, lo estético o lo religioso (Schmitt 2006: 65-66), y ni siquiera podría llegar a estarlo por enfoques "científicos" o "éticos" como ha aspirado el progresismo naif desde el triunfo histórico de la burguesía. Ahora bien, de esta autonomía no se sigue que lo político sea independiente de la historia efectiva y, por tanto, de las mediaciones. Schmitt confunde la autonomía de lo político con una fuerza absoluta basada en la fe y personificada en el soberano.

La decisión debe entenderse como curso, en efecto, pero como curso histórico ligado a la razón, ya que todo acontecimiento es -por desagradable o reprobable que resulte- históricamente razonable. Cuanto ocurre puede entenderse. Lo contrario conduce al milagro o instancias equivalentes, de ahí que Schmitt sostuviera en Teología Política que, «[e]n la jurisprudencia, el estado de excepción tiene un significado análogo al del milagro en la teología» (Schmitt 2001a: 43). La mencionada confusión lleva a suponer que la alternativa a la decisión schmittiana o es anacrónica como la filosofía hegeliana y el parlamentarismo o está condenada a fracasar por su monolítico racionalismo, como el del marxismo. Sin embargo, como estos veredictos, tal confusión no es afortunada. Omite que el marxismo no era un corpus sectario, lo cual se advierte al menos en el enfrentamiento entre ortodoxos y humanistas, y la influencia y vitalidad de Hegel en los marxistas críticos del mecanicismo, lo cual muestra que la filosofía hegeliana estaba lejos de ser un mero vestigio. El hecho de que intelectuales como Veblen y Korsch, entre muchos otros, fueran conscientes y declararan públicamente a ambos lados del Atlántico desde inicios del siglo XX hasta tiempos de Stalin este doble aspecto muestra que dicha omisión no sólo carga una confusión, sino que hay razones para pensar que era deliberada. El decisionismo parece tener su peso también aquí.

Schmitt tampoco yerra al entender el mito como un recurso. Pero obvia que también es discurso y curso. Reducirlo a imágenes parece otra de sus decisiones, lo cual es a todas luces 
contradictorio en tanto que declara que, por ejemplo, Maquiavelo es un mito. ¿Qué verosimilitud tiene decir que el maquiavelismo ha arraigado sólo con imágenes? Se puede considerar al florentino como una amenaza para el cristianismo y la democracia liberal, como constata Schmitt que se ha divulgado, pero no que esto haya arraigado sin discursos que, en efecto, han permitido cuestionarlo y revalorizarlo. Así lo hizo Hegel, y Schmitt lo reconoce (Schmitt 2004: 77). Y suponer que el mito es posterior al curso, como si fuera una suerte de auxilio de la historia en lugar de una parte constitutiva de esta, parece derivarse de la vinculación que Schmitt quiere ver entre lo mítico y la guerra, que siempre es «posibilidad real» de lo político (Schmitt 2006: 64). Pero el mito puede ser apático, configurar un ambiente sin despertar entusiasmos ni énfasis belicosos, e incluso celebrar la armonía y condenar la guerra, frente a lo que cree Schmitt como buen reaccionario.

No sin ironía, la presunta superioridad de la propuesta de Schmitt ante la crisis del parlamentarismo y las alternativas filosófico-políticas parece una decisión suya. Que lo nacional vinculado a una repetición sea lo que marca la "nueva política", al tiempo que se supone que lo político es autónomo en virtud de una decisión en un instante frente a la facticidad histórica y que esta genera burdas alternativas homogéneas que no deben de ser sino barridas por una suerte de mito genuino, comporta proposiciones arbitrarias y una pretensión de absolutismo en tanto que se asume que todo depende del decisionismo en cuestión. No por casualidad, desde su formulación originaria, Schmitt presupone que la imagen metafísica de cada época -como si fuera única y firmese corresponde con la de la soberanía ejercida (Schmitt 2001: 49). Y esta, según lo comentado, con el patriarca y su "misión". Por lo demás, este absolutismo no es equiparable al de Hobbes, quien subordina la legitimidad de la decisión a una ley que, si bien se ampara y potencia bajo el mito del Leviatán, como intuyó Schmitt, es acorde y aun posterior a un individuo posesivo radicalmente histórico: el del capitalismo que arraiga en el siglo XVII en Inglaterra (Macpherson 2005). Que este se desvanezca irremisiblemente para dar paso a la mencionada "nueva política" parece otra de las arbitrariedades del planteamiento del jurista.

Las nociones comentadas de decisión y mito muestran que el decisionismo schmittiano implica un absolutismo político. Ambas suponen la absolutización de una historia que es tal en tanto que irreductible. Y no sólo a cualquier elemento fáctico, como la economía o la moral, lo estético o lo religioso, sino a cualquier comprensión que no acepte el factor "milagro". Este no es tanto una posibilidad más o menos inesperada, lo cual debería ser postulado por cualquier concepción no mecanicista de la historia, cuanto el compromiso teológico con la imposibilidad de discutir el desarrollo de la historia y, por tanto, de convertirla en un problema filosófico. Esto, además de ser una gran aportación de Hegel, provoca el rechazo contrarrevolucionario de donde germina la teología política.

\section{CONCLUSIÓN}

Estoy con Chantal Mouffe cuando propone «pensar “con Schmitt contra Schmitt» (Mouffe 2007: 21). Hacer filosofía política hoy sin tomárselo en serio es un despropósito. Pero también considero que el posicionamiento al respecto ha de ser crítico y radical. Es en este sentido que me parece que se puede probar que las ideas más seductoras -y probablemente las más potentes- de Schmitt

son las más sesgadas de su planteamiento. Me refiero a las que he tratado en este artículo, las relacionadas con la decisión y el mito. En ambas se haya lo más relevante y problemático del decisionismo schmittiano. 
No pienso que este decisionismo se diferencie del hobbesiano por ser más o menos absolutista. Schmitt acertó al decir que Hobbes absolutizaba el aparato del Estado y quizás esto explica por qué su propuesta conduce -o incluso degenera en- positivismo jurídico, pero también es cierto que los planteamientos del jurista pueden encontrarse en posiciones alejadas de sus intenciones, como prueba el desarrollo de "su mirada" por parte de autores alejados de la propaganda nazi, según he señalado al inicio de este artículo. Y es que el decisionismo no aúna felizmente en un mismo frente a quiénes lo sostienen; no sólo a Hobbes y Schmitt, sino tampoco a los schmittianos.

Lo que singulariza al decisionismo schmittiano frente al hobbesiano es que es más arbitrario. La presencia fundamental y recurrente de la arbitrariedad, como prueban sus nociones clave de decisión y mito, hace de Schmitt un pensador necesariamente criticable y de dudoso ejemplo para quienes no pretenden subordinar la racionalidad a la fe. Aunque sea un autor de interés para la filosofía política, no hay que olvidar su condición primordial de teólogo político.

\section{Bibliografía}

Adorno, T. W. (2005). La jerga de la autenticidad. En: Dialéctica negativa. La jerga de la autenticidad. Madrid: Akal, 393-499.

Agamben, G. (1998). Homo sacer. El poder soberano y la nuda vida. València: Pre-textos.

Agamben, G. (2020). ¿En qué punto estamos? La epidemia como política. Buenos Aires: Adriana Hidalgo.

Burns, T. (2002). Joseph Dietzgen and the history of Marxism. Science \& Society, 66(2), 202-227.

Campos García-Calderón (2021). El fundamento teológico del concepto de soberanía de Carl Schmitt. La experiencia religiosa de la repetición. Revista Filosofía UIS. 20(1), 73-101.

Conrad, B. (2008). Kierkegaard's moment. Carl Schmitt and his rhetorical concept of decision. Redescriptions: Yearbook of Political Thought, Conceptual History and Feminist Theory, 12, 145-171.

Galli, C. (2011). La mirada de Jano. Ensayos sobre Carl Schmitt. México DF: FCE.

Han. B-C. (2020). La emergencia viral y el mundo de mañana. El País. Recuperado de: https://elpais.com/ideas/2020-03-21/la-emergencia-viral-y-el-mundo-de-manana-byung-chul-h an-el-filosofo-surcoreano-que-piensa-desde-berlin.html [Consultado el 23 de marzo de 2020]

Herrero, M. (2007). El nomos y lo político. La filosofía política de Carl Schmitt. Pamplona: EUNSA.

Hobbes, T. (1909). Hobbes's Leviathan. Oxford: The Clarendon Press.

Kierkegaard, S. (2005). Temor y temblor. Madrid. Alianza.

Kierkegaard, S. (2012). El Instante. Madrid. Trotta.

Kierkegaard, S. (2018). La repetición. Madrid. Alianza.

Korsch, K. (1978). Marxismo y filosofía. Barcelona: Ariel.

Löschenkohn, B. (2019). Occasional decisiveness: Exception, decision and resistance in Kierkegaard and Schmitt. European Journal of Political Theory, 18(1), 89-107.

Macpherson, C. B. (2005). La teoría política del individualismo posesivo. De Hobbes a Locke. Madrid. Trotta.

Marchart, O. (2009). El pensamiento político postfundacional. La diferencia política en Nancy, Lefort, Badiou y Laclau. México DF: FCE.

Mouffe, C. (comp.) (2011). El desafío de Carl Schmitt. Buenos Aires: Prometeo Libros.

Mouffe, C. (2007). En torno a lo político. México DF: FCE.

Orestes Aguilar, H. (2001). Carl Schmitt, teólogo de la política. México DF: FCE. 
Rossi, L. A. (1999). «El mito más fuerte reposa sobre lo nacional»: Carl Schmitt, Georges Sorel y El concepto de lo político. Revista Internacional de Filosofía Política, 14, 147-166.

Schmitt, C. (1934). Der Führer schützt das Recht. Deutsche Juristen-Zeitung 39, 946-950: Recuperado de: ht tp://www.flechsig.biz/DJZ34_CS.pdf [Consultado el 10 de enero de 2021]

Schmitt, C. (2001a). Teología Política I. Cuatro capítulos sobre la teoría de la soberanía. En: Orestes Aguilar (2001): 19-62.

Schmitt, C. (2001b). El "Führer” defiende el derecho. En: Orestes Aguilar (2001): 114-118.

Schmitt, C. (2003a). El nomos de la tierra. En el Derecho de Gentes del "Jus Publicum euopaeum". Buenos Aires: Struhart y Cía.

Schmitt, C. (2003b). Apropiación, partición, apacentamiento. En: Schmitt (2003a): 357-374.

Schmitt, C. (2004). El Leviathan en la teoría del Estado de Tomás Hobbes. Granada: Comares.

Schmitt, C. (2006). El concepto de lo político. Madrid: Alianza.

Schmitt, C. (2008). Los fundamentos histórico-espirituales del parlamentarismo en su situación actual. Madrid: Tecnos.

Schmitt, C. (2017). Estado, Movimiento, Pueblo. La triple articulación de la política. Eunomía. Revista en Cultura de la Legalidad 12, 273-309.

Schumpeter, J. A. (2000). La crisis del Estado fiscal. Revista española de control externo, 2(5), 147-192.

Sorel, G. (2005). Reflexiones sobre la violencia. Madrid: Alianza.

Swedberg, R. (1991). Schumpeter.A biography. Princeton, NJ: Princeton University Press.

Veblen, T. (1907). The Socialist Economics of Karl Marx and His Followers. The Quarterly Journal of Economics, 21(2), 299-322.

Windelband, W. (1960). Historia general de la filosofía. Barcelona: El Ateneo.

Notas

$1 \quad$ Introduciendo una edición de El concepto de lo político de 1963, en plena Guerra Fría, todavía mantiene que «[f]rente a la teología y a la filosofía, por un lado, y por el otro frente a los reajustes técnico-sociales, el jurista público se encuentra en una posición intermedia y a la defensiva; ya no puede contar con la intangibilidad autóctona de su posición, y la información contenida en sus definiciones está en suspenso» (Schmitt 2006: 45). El subrayado es mío [JM].

3 Esta idea de instante le sirvió de pretexto a Kierkegaard, al final de su vida, para declararle una virulenta ofensiva pública a la Iglesia de Dinamarca, entonces influida por la filosofía hegeliana, mediante una serie de textos teológicos (Kierkegaard 2012).

4 Incluso se ha remarcado que sus diarios muestran que leía a Kierkeggard para su edificación personal. Lo llega a llamar "el más sincero cristiano" [innerlischster aller Christien] (Conrad 2008: 157).

5 «Es increíble que en el sistema hegeliano se haya hecho tanto ruido en torno a la mediación y que, bajo esa misma enseña, gocen de honor y gloria las chácharas descabelladas del inmenso coro de sus prosélitos. Mucho mejor hubiera sido repensar a fondo lo que significa esa palabra y de este modo hacerles un poco de justicia a los griegos. Porque el desarrollo que hicieron los griegos de la doctrina del ser y de la nada, de la doctrina del instante y del no-ser, etc., pone fuera de juego a Hegel, dándole, si se me permite la expresión, jaque mate. La palabra mediación es un término extranjero, repetición es una buena palabra danesa y no puedo por menos que felicitar al idioma danés porque posee tal término filosófico» (Kierkegaard 2018: 70-71).

6 Es cierto que «no es un azar que un inglés del siglo XVII erigiese a un animal marino en símbolo del orden generador de paz, porque el Leviathan, "la gran ballena”, no era a la sazón un tema extraño a la fantasía del pueblo inglés» (Schmitt 2004: 16). Pero no es evidente ni que este mito fuera igualmente efectivo sobre toda la población inglesa, sobre todo la menos familiarizada con el océano, ni que su efectividad social y política 
estuviera libre de creencias vinculadas a discursos previos. Baste recordar el Libro de Job y el peso del Antiguo Testamento en los países donde arraigó la Reforma protestante.

7 La propaganda de la lucha de clases varía considerablemente en países que se diferencian entre sí por tradición cultural y nivel de desarrollo industrial, pese a la fuerza que tengan sus respectivos movimientos obreros incluso en una misma época, como puede ser el caso de Inglaterra, Alemania, Rusia e Italia en la década de 1920. Sobre este aspecto, la reflexión de Antonio Gramsci sigue siendo una referencia ineludible. 